\title{
Artigos
}

Andréa de Vargas Rodrigues Nina Bernal Balconi Simone Cintra

\section{Entre brisas, cantos e contos: especificidades da prática docente na Educação Infantil}

Resumo: $\bigcirc$ presente texto aborda vivências e reflexões construídas durante a disciplina de Estágio Supervisionado em Educação Infantil, do curso de Pedagogia da Universidade Federal de Santa Catarina (UFSC). Essa disciplina nos possibilitou experienciar o diálogo entre a teoria e a prática docente com crianças entre três a quatro anos de uma creche da Rede Municipal de Ensino de Florianópolis, SC. Abordamos o caminho percorrido do início da disciplina até a vivência de nossas práticas pedagógicas, e como o processo vivido com as crianças nos oportunizou refletir sobre as especificidades da prática docente na Educação Infantil, ressaltando o diálogo entre os Núcleos de Ação Pedagógica (NAP), que integram as Orientações Curriculares Municipais, a organização dos espaços e as relações que constituem os espaços coletivos de educação e cuidado.

Palavras-chave: Educação infantil; Estágio supervisionado; Especificidades da prática docente.

\section{Between breezes, songs and tales: specificities of teaching practice in early childhood education}

Abstract: This paper is about experiences and reflections built during the Supervised Internship in Early Childhood Education in the School of Education of the Universidade Federal de Santa Catarina (UFSC). This discipline has allowed us to experience the dialogue between theory and teaching practice with children from three to four years old in a Childhood Education Daycarefrom the public education in Florianópolis. We approach the path from the beginning of the course to the experience of our teaching practices, and how the process experienced with children provided us an opportunity to reflect on the specifics of teaching practice in early childhood education, emphasizing dialogue between the Núcleos de Ação Pedagógica (Pedagogical Action Centers) that integrate the Municipal Curriculum Guidelines, the organization of spaces and relationships that constitute the collective spaces of education and care.

Keywords: Childhood Education; Supervised Internship; Specifics aspects of teaching practice.

\footnotetext{
1 Graduanda em Pedagogia na Universidade Federal de Santa Catarina.E-mail: deia.vr@hotmail.com

2 Graduanda em Pedagogia na Universidade Federal de Santa Catarina. E-mail: ninabalconi@hotmail.com

3 Doutora em Educação pela Universidade Estadual de Campinas (UNICAMP). Professora substituta na área de Educação Infantil do Centro de Ciências da

Educação/Departamento de Metodologia do Ensino da Universidade Federal de Santa Catarina (CED/MEN/UFSC). E-mail: simonescintra@gmail.com
} 
este texto narramos e trazemos à discussão vivências e reflexões construídas durante a disciplina de Estágio Supervisionado em Educação Infantil, do curso de Pedagogia da Universidade Federal de Santa Catarina (UFSC). Uma disciplina que nos possibilitou experienciar o diálogo entre a teoria e a prática docente com crianças pequenas, uma vez que abarcou o estudo e a retomada de conceitos estudados ao longo do curso, o exercício docente com as crianças e a reflexão constante, tanto por meio do diálogo com a professora orientadora e com os profissionais do campo de estágio, como por meio da escrita de registros de observação, plano de ação pedagógica e do memorial - documento que traz a descrição e a análise de todo o processo vivido durante a referida disciplina e que nos serviu de base para a construção deste texto.

Ao iniciarmos essa etapa da nossa formação, questões nos provocaram com mais força. Neste sentido, foi impossível não revisitar o passado, pois estávamos nos constituindo como professoras nessa caminhada. Antes de ingressarmos no Curso de Pedagogia já trazíamos conosco algumas concepções de criança e de infância. Concepções advindas dos conhecimentos produzidos a partir do senso comum, baseadas em saberes distintos dos quais aprendemos ao longo destes anos em formação para a docência. Hoje sabemos que o nosso curso nos possibilitou compreender, como coloca Sônia Kramer (2007, p.14), que

\footnotetext{
[... ] as visões sobre a infância são construídas social e historicamente. A inserção concreta das crianças e seus papéis variam com as formas de organização da sociedade. Assim, a ideia de infância não existiu sempre e da mesma maneira. Ao contrário, a noção de infância surgiu com a sociedade capitalista, urbano-industrial, na medida em que mudavam a inserção e o papel social da criança na sua comunidade.
}

De tal modo, passamos a conhecer a construção da história da infância pelo viés de vários estudiosos, os quais contribuíram para a nossa compreensão sobre o reconhecimento das crianças como sujeitos sociais e históricos; sujeitos de diretos e valorizando suas vozes.

Foi com muito estudo que passamos a compreender que esses direitos, tão falados e discutidos durante o nosso processo de formação, englobam o modo como nós adultos compreendemos e nos relacionamos com as crianças, percebendo-as na "sua alteridade e pelo valor 
que têm em si mesmas, pelo o que as constitui no tempo presente, pelo que lhes é específico, e não pelo o que se espera ou se projeta para elas" (BORBA, 2009, p.102). Passamos, também, a compreender que ao professor cabe assumir um compromisso com a criança, entendendo que ela é capaz de construir suas relações e produzir sua própria cultura. Vendo-a e ouvindo-a como um ser concreto (ROCHA; OSTETTO, 2008).

A retomada dessas desconstruções conceituais marcou o início da nossa vivência no Estágio em Educação Infantil, pois foi a partir dela que nos preparamos para estar com as crianças, participando do seu cotidiano, interagindo, observando e registrando as "múltiplas formas de expressão que elas utilizam para se comunicar e ser no mundo" (ROCHA; OSTETTO, 2008, p.104). Um processo complexo e desafiador, mas que foi fundamental para o nosso exercício docente e para a elaboração das ações pedagógicas que realizamos para e com as crianças do Grupo 4B da Creche Orlandina Cordeiro, da Rede Municipal de Ensino de Florianópolis, SC.

Se considerarmos os indicativos que Luciana Ostetto nos dá em seu texto "Planejamento na educação infantil: mais que a atividade, a criança em foco" (2000), podemos afirmar que buscamos pensar as crianças do G4B - 13 meninas e 7 meninos, com idades entre 3 e 4 anos - como sujeitos que brincam, aprendem, criam e se divertem, mas também sujeitos que nos convidam a brincar, nos ensinam, ampliam nossos saberes e nos acolhem. Nesse sentido, procuramos, em um primeiro momento, construir uma relação com as crianças. Quando a autora nos questiona

[...] quanto temos brincado com as crianças? [...] Ajudamos o grupo de crianças a estruturar repertórios que enriqueçam suas brincadeiras? Há, enfim, espaço para a criação de brincadeiras, nas nossas salas, nos diversos ambientes da instituição em que trabalhamos com as crianças? [...] E a linguagem? O que temos feito dela em nossas salas de trabalho? Quantas formas de expressão ganham lugar no dia-a-dia com a criança? Há espaço para a diversidade de dizeres e saberes das crianças? Há espaço para as cores do arco-íris ou para azuis e amarelos, somente? Pode rabisco? E sol com olhos e boca? [...] Pode cantar, correr, movimentar-se? E ouvir histórias? [...] E narrar coisas vividas? (OSTETTO, 2000, p. 192).

Podemos responder: sim! Além destas questões serem abordadas em nosso planejamento, tentamos fazer um movimento de permitir que as próprias crianças nos guiassem por caminhos que dialogassem com estas perguntas.

Portanto, nossa forma de planejar e (re)planejar nossas ações junto às crianças foi baseada em um movimento de reflexão e diálogo entre nós (estagiárias), orientadora, professoras da Instituição e, principalmente, as crianças. Ouvi-las foi nosso fio condutor dessa experiência para, assim, encontrarmos indícios de possibilidades a serem exploradas e construídas junto e com as crianças. Trazemos novamente as ideias de Ostetto (2000) sobre as especificidades e necessidades do 
planejamento na Educação Infantil:

\begin{abstract}
Não adianta ter um "planejamento bem planejado", se o educador não constrói uma relação de respeito e afetividade com as crianças; se ele toma as atividades previstas como momentos didáticos, formais, burocráticos; se ele apenas age/atua mas não interage/partilha da aventura que é a construção do conhecimento para o ser humano. Para mim, elaborar um "planejamento bem planejado" no espaço da educação infantil significa entrar na relação com as crianças (e não com os alunos!), mergulhar na aventura em busca do desconhecido, construir a identidade de grupo junto com as crianças. (p. 190).
\end{abstract}

E foi neste movimento, apontado pela autora, que planejamos nossas ações, de forma que pudéssemos nos envolver com as crianças e participar da experiência junto com elas. Desse modo, nosso planejamento foi (re)construído apoiado nas observações que fizemos nas primeiras semanas e durante todo o período que estivemos na Instituição.

Assim, a partir dos indicativos das crianças, e em diálogo com o Núcleo de Ação Pedagógica (NAP): Relações com a Natureza: manifestações, dimensões, elementos, fenômenos e seres vivos, que integra as Orientações Curriculares para a Educaşão Infantil da Rede Municipal de Ensino de Florianópolis (2012), planejamos ações para diferentes momentos da rotina do grupo, tendo a brincadeira e a imaginação como fio condutor para o desenvolvimento de nossas ações, pois

[...] a imaginação é para a criança um espaço de liberdade e de decolagem em direção ao possível, quer realizável ou não. A imaginação da criança move-se junto — comove-se — com o novo que ela vê por todo o lado no mundo. Sensível ao novo, a imaginação é também uma dimensão em que a criança vislumbra coisas novas, pressente ou esboça futuros possíveis. Ela tem necessidade da emoção imaginativa que vive por meio da brincadeira, das histórias que a cultura lhe oferece, do contato com a arte e com a natureza, e da mediação adulta: o dedo que aponta, a voz que conta ou escuta, o cotidiano que aceita (GIRARDELLO, 201 I , p.76).

Ainda como parte de nosso planejamento, pensamos em diferentes modos de organização dos espaços da sala e da parte externa da creche, uma vez que compreendemos que os espaços para além da sala também são espaços educativos que permitem potencializar a aprendizagem e o desenvolvimento das crianças e de suas relações entre si, com os adultos e com o mundo.

E, assim, um tanto mais confiantes, vivenciamos o planejado com as crianças. A cada dia nos víamos em meio a muitas descobertas, questionamentos, mudanças de planos e, constantemente, surpreendidas com tamanha sabedoria e envolvimento do grupo. Vivemos plenamente o movimento de estar docente com as crianças do G4B e essa vivência nos deu também a possibilidade de refletirmos sobre algumas das especificidades do exercício docente da educação infantil. 
Abordamos essas reflexões no item que se segue.

\section{O exercício docente na educação infantil e suas especificidades}

Durante e ao final de nosso exercício docente refletimos sobre como as práticas vivenciadas com o G4B nos permitiram a aproximação com o caráter da docência para e com as crianças pequenas. Esta reflexão se deu em diálogo com nossos registros escritos e fotográficos e, também, com conceitos e reflexões trazidos por estudos e documentos oficiais acerca da prática docente na educação infantil.

Nossas reflexões nos conduziram a diferentes aspectos que integram a docência com as crianças pequenas. Esses aspectos serão abordados a seguir. Porém, antes disso, chamamos a atenção para um aspecto que, para nós, perpassa todos os outros: a forma como as relações se constituem nos espaços educativos, como nós e as crianças construímos relações que se diferem, mas que ao mesmo tempo conversam.

Como escreveu Schmitt (2011), dialogando com o conceito de polifonia de Bakhtin:

A pertença de cada criança em diferentes grupos, ou num grupo específico, induz suas ações e seus comportamentos, inclusive de consumo. Isto faz com que a criança se identifique com os grupos nos quais é incluída, por uma política de inclusão. Tal política de inclusão produz os excluídos.

Nesse sentido, reiteramos que nosso modo de pensar as especificidades da docência na Educação Infantil, considera que esta é uma docência que acontece em meio a muitas relações e que estas relações, por sua vez, acontecem em meio a diferentes vozes.

\section{I . I Núcleos de Ação Pedagógica: os NAP!}

Em seu texto Diretrizes Educacionais Pedagógicas para a Educação Infantil, que integra dois documentos da Secretaria Municipal de Educação de Florianópolis ${ }^{4}$, Eloisa Rocha explicita que a função da educação infantil,

[...] sustenta-se no respeito aos direitos fundamentais das crianças e na garantia de uma formação integral orientada para as diferentes dimensões humanas (linguística, intelectual, expressiva, emocional, corporal, social e cultural), realizando-se através de uma ação intencional orientada de forma a contemplar cada uma destas dimensões como núcleos da ação pedagógica (ROCHA, 20 I 0, p. I2; grifos nossos).

4 FLORIANÓPOLIS, PMF. SME. Diretrizes Educacionais Pedagógicas para a Educação Infantil. Florianópolis: Prelo Gráfica e Editora Ltda, 2010. Disponível em: http://mwn.pmf.sc.gov.br/arquivos/arquivos/pdf/12_05_2010_15.24.41.03c7e67bbe979ef30c2efe7d/ db / 468a.pdf

FLORIANÓPOLIS, PMF. SME. Orientações Curriculares para a Educação Infantil da Rede Municipal de Ensino de Florianópolis. Florianópolis: Prelo Gráfica e Editora Ltda., 20 I 2. Disponivel em: http://mww.pmf.sc.gov.brlentidades/educa/index.php?cms=legislacao + +leis +e +orientacoes\&menu=9 
Os núcleos da ação pedagógica (NAP) são explicados pela autora como orientadores de uma ação docente que possa possibilitar às crianças vivenciarem e estabelecerem relações com a natureza, com as linguagens, entre si, com os adultos e com a cultura. O texto aborda, ainda, os conteúdos de cada NAP, "de forma a orientar os objetivos gerais de cada núcleo e suas consequências para a prática docente" (ibid., p.14). Os NAP são também abordados no documento Orientações Curriculares para a Educação Infantil da Rede Municipal de Ensino de Florianópolis (2012), que traz capítulos separados, cuja autoria não é mencionada, para cada núcleo: "Relações Sociais e Culturais", "Linguagens: Oral e Escrita; Visual; Corporal e Sonora", "Relações com a Natureza: manifestações, dimensões, elementos fenômenos e seres vivos".

Entendemos que os NAP fazem parte das dimensões da docência na Educação Infantil porque, como esclarece Rocha (2010), tanto a função social da educação infantil, como os núcleos de ação pedagógica influenciam na "definição do caráter da docência, ou seja, do papel das professoras e professores" (p.12). Eles estão intimamente relacionados ao planejamento da ação pedagógica, não como conteúdos escolares, mas sim como possibilidades para a organização de "situações significativas que viabilizem experiências das crianças com o mundo físico e social, em torno das quais se estruturem interações qualitativas entre adultos e crianças, entre crianças e crianças, e entre crianças e objetos/mundo físico" (OSTETTO, 2000, p.193).

Outro aspecto importante sobre os NAP refere-se à necessidade de não serem entendidos de forma dissociada, pois, como também esclarece Rocha (2010):

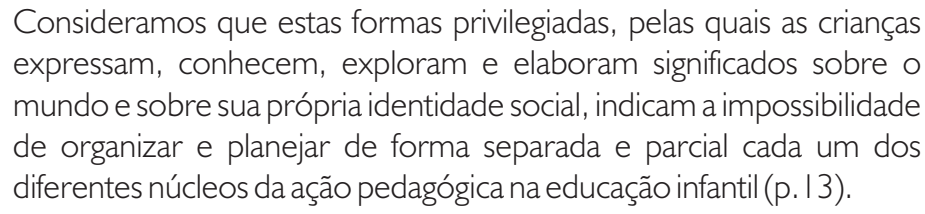

Desde o início, quando começamos a pensar nosso planejamento, tivemos a preocupação de compreender os NAP de forma dialógica. Nesse sentido, ao planejarmos ações que privilegiavam as relações com a natureza e seus elementos, também buscamos explorar diferentes linguagens e as relações sociais e culturais, não deixando de lado informações e conhecimentos que dialogavam com as propostas. Porém, somente após a nossa docência pudemos dimensionar os efetivos diálogos que nossas práticas pedagógicas tinham conquistado. Assim, trazemos a seguir nossas reflexões sobre as "Linguagens Visuais" em parceria com as "Relações com a Natureza" e, também, nossas reflexões a partir de proposições que tiveram como foco as "Linguagens Corporais e Sonoras" e "Linguagens Oral e Escrita". 


\title{
I . I . I As Relações com a Natureza e as Linguagens Visuais
}

\begin{abstract}
Se a criança vem ao mundo e se desenvolve em interação com a realidade social, cultural e natural, é possível pensar em uma proposta educacional que the permita conhecer este mundo, a partir do profundo respeito por ela. Ainda não é o momento de sistematizar o mundo para apresentá-lo à criança: trata-se de vivê-lo, de proporcionar-lhe experiências ricas e diversificadas (KUHLMANN JR, 1999, apud FLORIANÓPOLIS, NAP: Relações com a Natureza, 2012, p.6).
\end{abstract}

É com esta epígrafe que começamos as nossas reflexões sobre as proposições orientadas, mais pontualmente, a partir do "NAP: Relações com a natureza" e em diálogo com o "NAP: Linguagens Visuais". Partindo dela conseguimos dizer que possivelmente nós só amamos o que respeitamos. Então, por que não cultivar o respeito pelo mundo, ao invés de dizer às crianças que elas devem amá-lo? Quando a criança entende - e no caso das crianças pequenas o correto seria dizer, sente e incorpora - que respeitar a natureza, as pessoas e o mundo no qual vivemos é uma forma de amá-los, a educação se torna apenas uma pincelada colorida em meio ao que será a entrega deste ser ao mundo que o rodeia. Entregar-se é uma forma de aprender com o mundo que está posto, com a realidade social, cultural e natural. Então, quando a criança vive o mundo, e não somente o observa, ela passa a respeitá-lo, pois se sente parte incondicional dele. Desse modo, nossa prática pedagógica foi organizada com o propósito de mediar estas vivências, ouvindo, reelaborando e propondo formas diversificadas de relação das crianças com o mundo.

Neste percurso buscamos ampliar as possibilidades das crianças de exploração de elementos naturais que levamos para compor suas brincadeiras e produções visuais, assim como, daqueles elementos presentes nos espaços externos da creche e em seus arredores. Buscamos, também, ampliar essa exploração por meio da vivência de práticas com as linguagens visuais a partir de elementos naturais, e do contato com brinquedos artesanais que produzimos para o grupo.

Para iniciar as práticas pedagógicas, levamos para o grupo uma caixa com diferentes elementos da natureza para que as crianças brincassem e se familiarizassem com materiais naturais, elas puderam descobrir muitas formas de se relacionar com aquele universo e outras tantas formas de ressignificar o que estava posto pela função de cada objeto. Essas descobertas, porém, necessitaram da nossa mediação, que se deu por meio da exploração dos objetos da caixa juntamente com as crianças:

Assim que abrimos a caixa, todos pegaram os cata-ventos. Os tocos grandes também foram boa atração. Com todos entusiasmados com os cata-ventos, fui retirando aos poucos outros elementos da caixa e assim as crianças começaram a reparar o que havia ali e que antes não haviam reparado. As rodinhas furadas serviram como aparador de cata-vento. Com os tocos grandes e os gravetos em cima deles, 
fizemos pontes. As pedras viraram instrumentos musicais quando batidas umas nas outras. As varetas eram baquetas de bateria (com uma lata e balde que a professora do grupo nos deu). Uma das crianças pedia para Déia cantar enquanto ela batucava na lata e outra as acompanhava. Aos poucos tudo foi se modificando. As pedras e rodinhas já eram elementos de troca e venda na vendinha da máquina registradora. Enquanto os tocos grandes eram banquinhos para sentar (Registro Nina - 13 de maio de 20|4).

Imagens I e 2 - Crianças brincando e ressignificando os elementos da natureza e as brincadeiras com os materiais disponibilizados pelas estagiárias
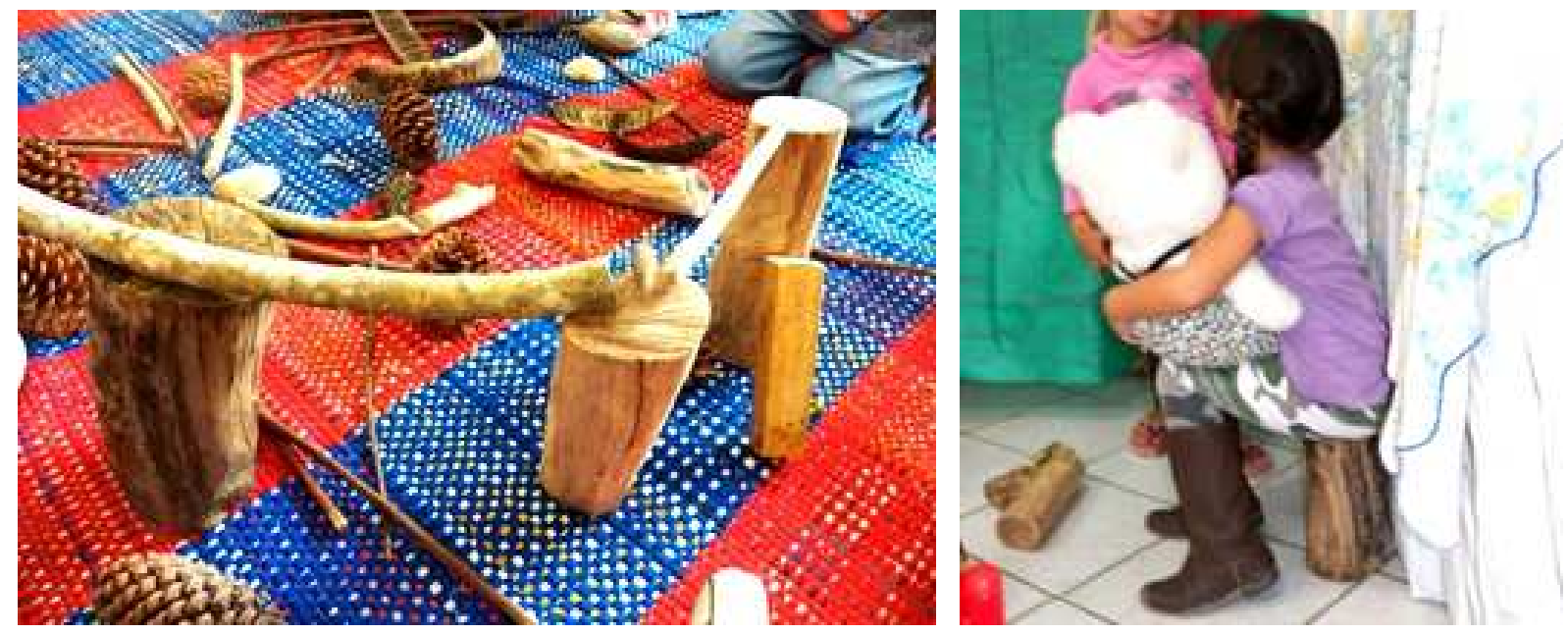

Imagem 3- Crianças utilizando os elementos da natureza para fazer um "churrasco"

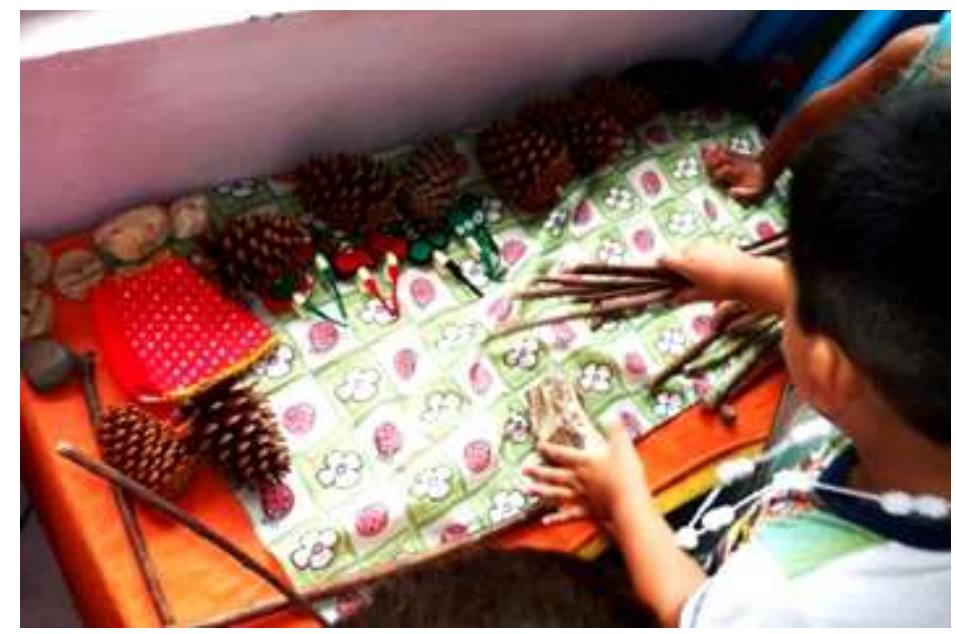

Não esperávamos tamanho "protagonismo de enredos" das crianças a partir da exploração dos elementos naturais e dos brinquedos artesanais. Mesmo já tendo sido alertadas por Girardello (2011), que o contato com a natureza é importante para a imaginação da criança, vê-las ressignificar, de forma tão imaginativa, os diversos materiais disponibilizados nos deixou surpresas. A autora cita obras de Gaston Bachelard para nos apresentar uma importante reflexão sobre a relação entre a 
criança, a natureza e a imaginação:

Para Bachelard, a relação com a natureza é mesmo a grande matéria da imaginação infantil: "o devaneio na criança é um devaneio materialista. A criança é um materialista nato. Seus primeiros sonhos são os sonhos das substâncias orgânicas" ( I 994, p. 9), diz Bachelard, remetendo aos elementos — o fogo, o ar, a água e a terra — que para ele são "os hormônios da imaginação" (1990, p. 12). (GIRARDELLO, 20 I I, p. 78).

Nesse sentido, seria inevitável que as crianças brincassem, reinventassem e imaginassem em diálogo com todo o universo que saia daquela caixa. Porém, vê-las fazendo tudo isso foi um grande aprendizado para nós, pudemos vivenciar a potência da imaginação infantil descrita por Bacherlad (1990; 1994) e Girardello (2011).

A possibilidade de explorar ao máximo os cantinhos da creche se tornou um dos objetivos centrais de nossas ações junto ao grupo. Um grande exemplo disso foi a elaboração e realização da nossa "caça ao tesouro". Conversamos muito, antes e durante a criação do percurso, sobre os espaços disponíveis da instituição e isso possibilitou uma reflexão entre o possível e o imaginado. Tivemos a tarefa de sistematizar diferentes dados - enredo das charadas e das pistas, contexto e propósito das cartas/bilhetes, idade das crianças, tempo de duração da proposta, interferências climáticas, quantidade de crianças e de adultos envolvidos, entre outros - e este planejamento possibilitou estarmos mais preparadas no momento da realização da brincadeira, mas também que diversificássemos o olhar durante sua realização e tivéssemos informações para reflexões posteriores.

Imagem 4 e 5-Crianças, professora do grupo, professora Simone e estagiária Nina procurando as pistas para encontrar o tesouro
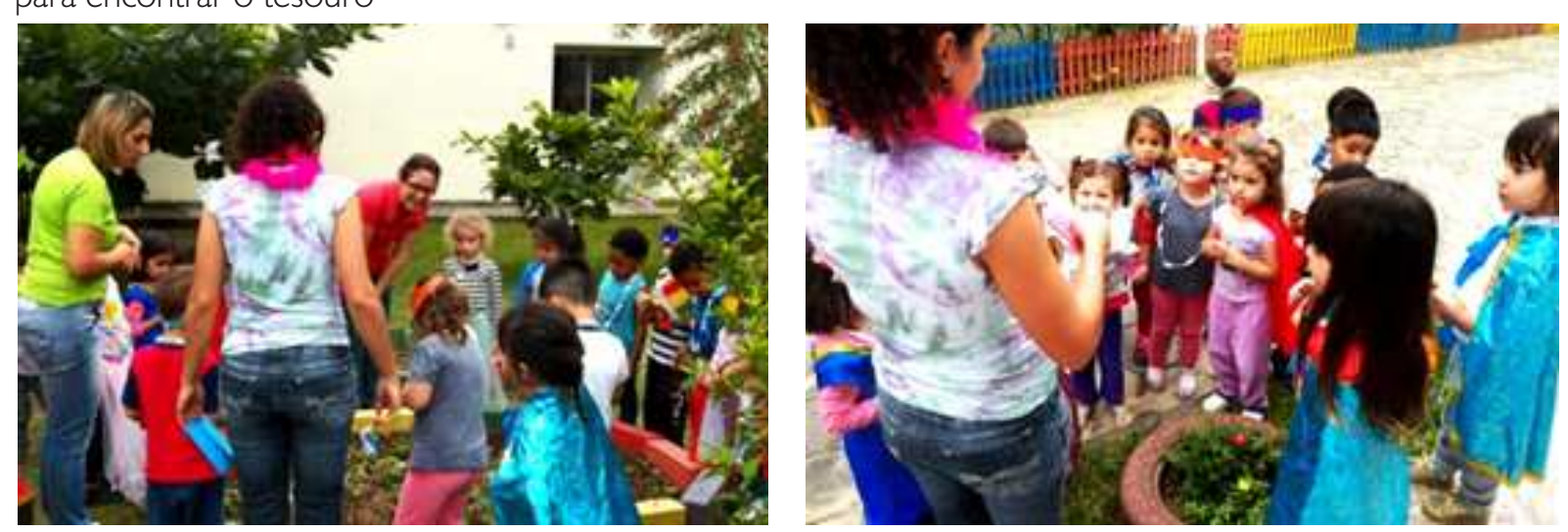

Além da exploração dos espaços externos da creche, que foi intensa, essa proposição trouxe às crianças outros elementos naturais, pois o tesouro, que de acordo com o enredo da brincadeira havia sido escondido pela Fada Azul (personagem interpretada pela professora auxiliar da parte da 
manhã, que vem sempre visitar o grupo e também envia surpresas), estava repleto deles. Alguns foram incluídos à caixa coletiva, outros mostrados às crianças e reservados para um momento de pintura e teve ainda o elemento que, talvez, tenha sido o mais valorizado naquele momento: a pedra preciosa que a Fada mandou para cada criança, embrulhada com tecido tule e fita colorida. Um presente recebido com grande alegria e que trouxe a possibilidade das explorações e vivências junto à natureza e seus elementos chegarem às famílias:

Foi um momento importante, pois percebemos que as crianças gostaram muito, guardavam a pedra nas mochilas com muito carinho. E quando os pais chegavam para buscá-las, contavam entusiasmadas da caça ao tesouro e da pedra preciosa (Registro Andréia - 14 de maio de 20|4).

Aqui destacamos o envolvimento crescente das crianças com relação à exploração dos espaços externos e dos elementos naturais, já que uma levava à outra: as idas ao pátio e ao parque estavam sendo ressignificadas e a natureza estava presente na sala. Pudemos, também, refletir sobre esse envolvimento no dia em que levamos instrumentos musicais feitos por nós com elementos naturais e que produziam sons da natureza. Antes de apresentarmos cada instrumento para as crianças, cantamos e tocamos flauta como forma de incentivo aos diferentes sons. Ao mostrarmos os instrumentos (reco-reco, chocalho, percussão de coco, pau de chuva, chocalho de chuva) as crianças se entusiasmaram e batucaram alguns ritmos.

Nos últimos dias de nossas proposições, reparamos que os paus de chuva feitos de bambu, que no começo estavam verdes, secaram e estavam rachados. Quando as crianças perceberam este fato houve um pequeno espanto, nós conversamos sobre deterioração da natureza e a forma como a madeira 'trabalha' através do tempo, mas mesmo assim as crianças queriam continuar brincando e tocando suas músicas. Se tivéssemos mais meses de docência com elas poderíamos pensar, a partir dessa indicação das crianças, proposições relacionadas à decomposição dos materiais. Vivenciar o processo de maturação de alguns elementos naturais pode ser um caminho simples e rico para a aprendizagem das crianças. Conforme indicação do próprio NAP: Relações com a Natureza é importante observar como as crianças

[...] se relacionam com os elementos da natureza (ar, terra, água, fogo), o que pensam sobre os fenômenos físicos (chuva, vento, ondas do mar, tornado, etc.), químicos (o cozimento de um bolo, a mancha da água sanitária num tecido, a corrosão de determinado material) e biológicos (apodrecimento de uma fruta, metamorfose da borboleta, nascimento/reprodução e morte dos seres vivos), com os objetos e os usos que fazem deles, tanto na dimensão simbólica quanto na relação de manipulação e exploração, assim como as experiências que a esse tema se agregam. Esse processo de observação, seguido de registro e reflexão, é que permitirá conhecer e participar das experiências das crianças - tanto individuais como coletivas - e promover ações no 
sentido de planejar e organizar espaços e tempos, assim como suportes materiais e imateriais que lhes deem condições para ampliar essas experiências, desenvolver estratégias de observação, exploração e investigação, que permitam as primeiras aproximações com as explicações científicas, formulações de novas perguntas, de criar outros jeitos de lidar com os objetos, com a natureza, consigo mesmas e com a cultura mais ampla. (FLORIANÓPOLIS - NAP: Relações com a Natureza, 20 I 2, p.8-9).

Pudemos perceber esta cultura mais ampla, mencionada no trecho acima, na proposta da pintura com os elementos da natureza. Esses elementos também eram presentes enviados pela Fada Azul e que estavam escondidos junto ao tesouro. As crianças se mostraram conhecedoras das especiarias que estavam separadas em saquinhos transparentes: "esse vermelhinho tem cheiro de arroz" falou umas das meninas ao se referir ao colorau. Todas quiseram cheirar e tocar os elementos, os com tons mais avermelhados e amarelados eram mais disputados. A mistura da água com as especiarias e o entusiasmo das crianças com a pintura, possibilitou que trouxéssemos "como referência a criação de outras relações com o mundo físico e natural [...] que incluem a interação, a ludicidade, a brincadeira, as linguagens, a criação e a imaginação" (NAP: Relações com a Natureza, 2012, p.5). Deste modo, as crianças puderam explorar alguns elementos que constituem a linguagem visual como, por exemplo, cor, textura e forma. Segundo as orientações que integram o NAP: Linguagens Visuais,

[...] é preciso garantir às crianças que brinquem e descubram o imensamente pequeno, como as partículas do grão de areia e o imensamente grande, como o universo; que tenham assombros e sintam a emoção estética diante da multiplicidade da natureza explorando ludicamente, ou seja, brincando, suas formas cores, sabores, odores e que, por exemplo, mergulhem no desconhecido das profundezas dos oceanos. Enfim, é preciso promover experiências nas quais as crianças possam descobrir espantosas qualidades do mundo artístico, cultural e da natureza [...] (FLORIANÓPOLIS - NAP: Linguagens Visuais, 2012, p.5).

Assim, o momento da pintura com os elementos naturais nos proporcionou refletir a respeito da profundidade com a qual as crianças interagiram com aquela nova experiência. Queriam pintar com todas as cores ao mesmo tempo, brincavam entre cores (elementos), água e aromas. Pintavam, se sujavam, lavavam as mãos na água da bacia, sentiam o cheirinho dos elementos, esfregavam o dedo no papel e transformavam aquela pequena folha branca em uma aquarela perfeita.

Com essa proposição, mais uma vez o diálogo entre os núcleos de ação pedagógica se efetivava e as crianças se relacionavam com os elementos da natureza ao mesmo tempo em que vivenciavam a experimentação de elementos das linguagens visuais, ampliando, por meio desse diálogo, "sua sensibilidade, percepção, imaginação e, ao mesmo tempo, seu saber sensível e 
Imagem 6-Criança pintando com elementos da natureza

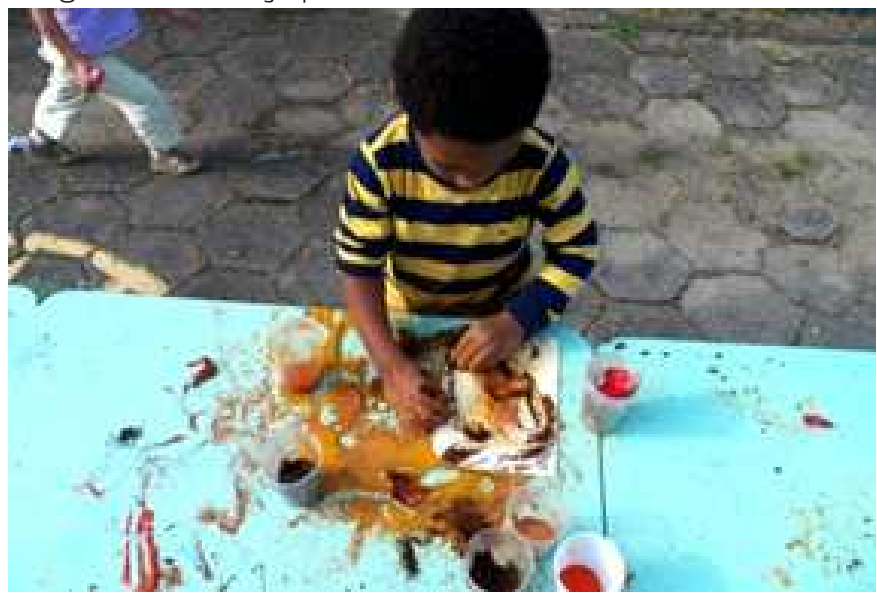

Imagem 7-Aquarelas e pinturas prontas

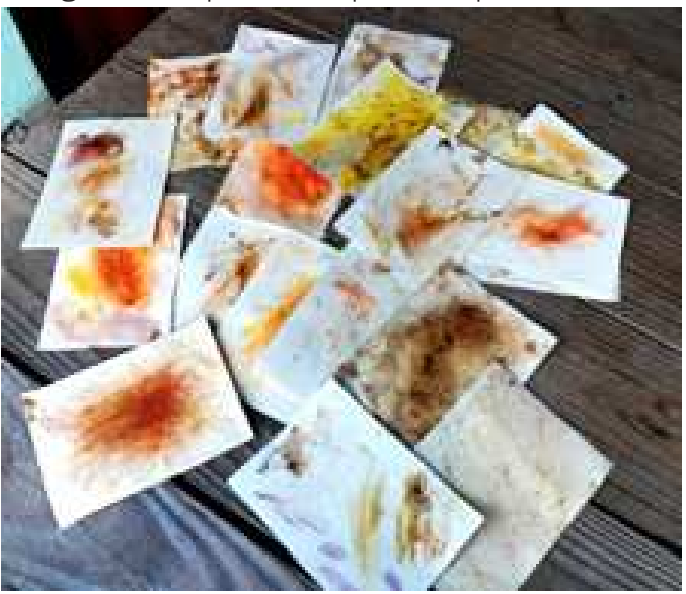

intelectivo" (FLORIANÓPOLIS - NAP: Linguagens Visuais, 2012, p.5).

Em nosso último dia de exercício docente junto ao grupo G4B, organizamos um pequeno passeio à Praça Djair Kurt, que fica 350 metros da creche. Com este passeio, entre outros objetivos, buscamos "promover a participação ativa das crianças na exploração, observação, valorização da paisagem local [...]” (FLORIANÓPOLIS, NAP: Relações com a Natureza, 2012, p.10). Porém, não deixamos de considerar que os passeios promovem e são combustíveis à nossa imaginação, uma vez que a magia que o passeio pode proporcionar às crianças irá acompanhá-las até a idade adulta.

Como fomos caminhando, o passeio foi se justificando também nesse trajeto creche/praça, pois o contato com as ruas do bairro, no qual mora grande parte das crianças, possibilitou a observação de espaços urbanos naturais, construídos ou alterados pela ação humana, potencializando a percepção das crianças como integrantes, dependentes e transformadoras do mundo, mostrando-se, também, como uma maneira de contemplarmos nossos objetivos ao tomarmos o "NAP - Relações com a Natureza: manifestações, dimensões, elementos fenômenos e seres vivos" como um dos orientadores da nossa ação pedagógica.

Durante toda a nossa estada na praça, nós e as professoras do grupo, incentivávamos a interação das crianças com a natureza local. Assim,

após um tempo, convidei duas crianças para irem ao outro lado da praça para subirem em uma árvore. Esta árvore tinha os galhos e troncos caídos e era fácil subir em alguns lugares dela. Aos poucos outras crianças começaram a ir até onde estávamos. Um dos meninos achou um galho perfeito para se pendurar e as outras crianças também quiseram. Então fizemos uma fila para que cada um pudesse ficar pendurado e ter a sensação de pular de um lugar um pouco mais alto. Algumas meninas viram seiva em uma árvore ao lado e me chamaram para mostrar. Perguntaram o que era e expliquei que a seiva é o alimento das plantas. Elas, então, compararam com leite - pela cor (Registro Nina - 03 de junho). 
Assim, pudemos perceber as crianças estabelecendo muitas e variadas relações com a natureza, com seus elementos e com a vida. Quando fazemos a mediação de um conhecimento para uma criança que reconhece aquele certo aprendizado já é significativo, mas quando essa mediação é fruto da iniciativa da própria criança se torna algo riquíssimo e de grande importância para os aprendizados que o exercício da docência nos traz.

Imagens 8 e 9 -Crianças brincando nas árvores
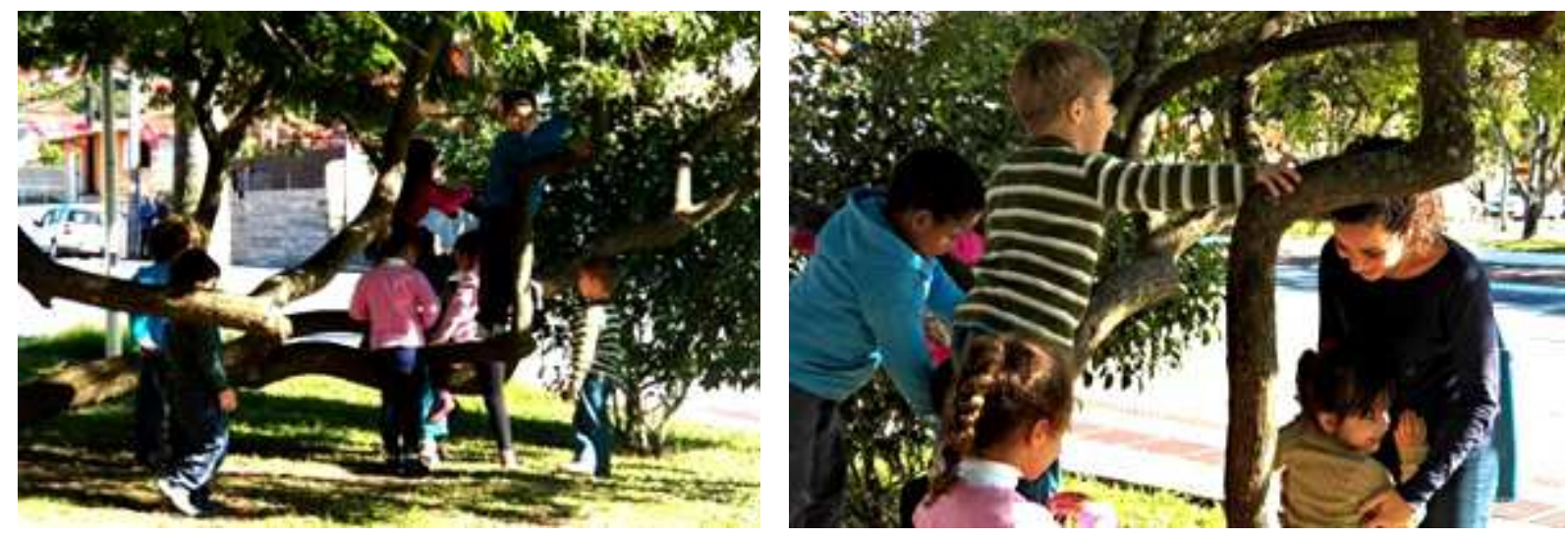

Como parte integrante dos objetivos do nosso planejamento, os momentos do lanche também foram foco de nossas ações. Buscamos intervir de forma que estes momentos também proporcionassem a observação e exploração dos elementos da natureza pelas crianças. A cada dia criávamos diferentes ambientes acolhedores, sempre utilizando velas, conchas, pedras preciosas e ramos de trigo. Nos primeiros dias fizemos uma grande roda no tapete e no centro colocamos a toalha, vela, trigo e algumas pedras. Muitas crianças ficaram curiosas e

\footnotetext{
quando eu acendi a vela as crianças começaram a cantar "Parabéns pra você" sem parar. Perguntavam-me quem estava de aniversário. Expliquei que a vela era para deixar o nosso lanche mais bonito e que o fogo é um dos elementos da natureza. As crianças gostaram da vela e chegavam bem pertinho para ver como funcionava aquela "luzinha" quente (Registro Andréa - I 4 de maio de 20 |4).
}

Em outro dia, organizamos as mesas de forma em que todas as crianças pudessem lanchar juntas, colocamos um paninho de crochê branco, velas, pedras e conchas em cada mesa. Assim lanchamos e conversamos a respeito dos elementos da natureza que estavam compondo a mesa. " $A s$ crianças ficaram curiosas sobre a chama, mas hoje foram as pedras e conchas que chamaram a atenção. Elas se lembraram das pedrinhas que a Fada Azul tinha dado de presente e também nos contaram que as conchas vêm do mar" (Registro Nina - 19 de maio de 2014). 
Imagens 10 e II - Lanche com vela, pedras preciosas e ramos de trigo
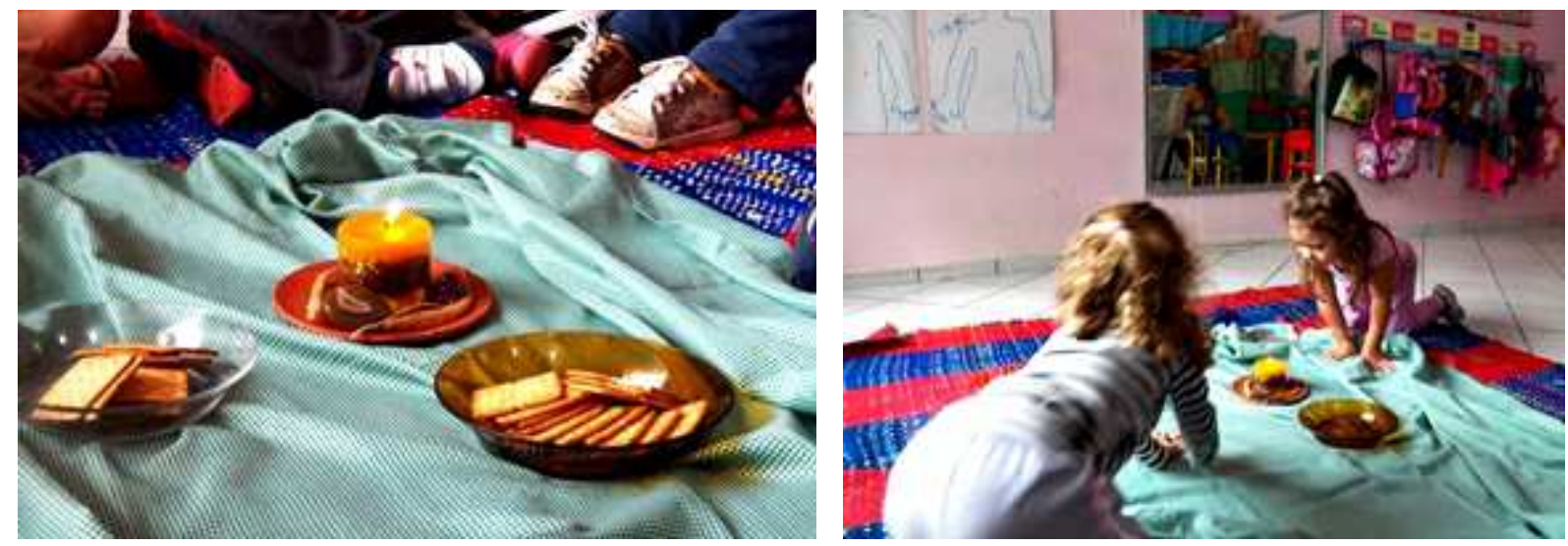

Para os momentos do lanche, decidimos que não iríamos intervir com explicações sobre os motivos de aqueles elementos estarem dispostos na mesa ou na toalha, sempre iríamos esperar que os questionamentos partissem das crianças. Acreditamos que a mediação tem caráter fundamental na prática docente com as crianças. Porém, a intencionalidade pedagógica também pode estar neste movimento de expor, literalmente, o novo para as crianças e deixar que a imaginação tome conta do momento. Estudiosa no assunto, Girardello (2014), nos lembra que quando a criança dispõe de tempo, um quase tédio, ou, como aconteceu em nossa experiência, a sonolência após o acordar, a imaginação infantil desabrocha e ela pode enxergar no mais simples objeto - velas, conchas, pedras um mar de ideias a navegar calmamente em diversas direções. Então, nos questionamos por que não permitir que o momento do lanche, em que as crianças se alimentam poucos minutos depois de acordar, seja este ambiente calmo e imaginativo?

E realmente esses momentos possibilitaram ao grupo a calmaria e a efervescência imaginativa, além de mais uma vez proporcionar a relação com os elementos da natureza, um dos focos de nossa ação pedagógica e que pode ser explorado nos diferentes momentos que compõe a rotina na Educação Infantil.

Finalizamos nossas reflexões, sobre o diálogo entre os NAP aqui abordados, com um indicativo muito importante para nós sobre a relação das crianças com a nossa prática pedagógica. Durante a avaliação da nossa estada na creche, a professora do grupo nos contou que as crianças estavam fazendo relações com as nossas proposições quando não estávamos presentes. Relatou que uma das crianças encontrou um toco seco no parque e ao ser questionada por ela sobre o que pretendia fazer com aquilo, a criança respondeu que iria levar para nossa caixa de elementos da natureza que estava na sala desde o primeiro dia de nossa docência. Este relato nos mostra como estimulamos e sensibilizamos o grupo e como foram significativas nossas intervenções. As indicações das crianças e das professoras nos alimentaram durante todo o estágio e nos auxiliaram a sustentar o olhar sensível que tanto tentamos trazer à nossa prática. Portanto, fomos tocados a todo 
instante - adultos e crianças - por essas “outras vozes” (SCHMITT 2011, p. 19) que encontramos no caminho.

\section{I .2 As Linguagens: Corporais, Sonoras, Oral e Escrita}

\section{Contarolando eu vou, contador de história eu sou}

Entrelaçadas às nossas proposições de vivências com a natureza estavam, também, organizadas situações que abarcavam as linguagens corporais e sonoras; oral e escrita. Essas situações nos proporcionaram momentos ricos de reflexão. Nesse sentido, o Núcleo de Ação Pedagógica (NAP): Linguagens Corporais e Sonoras ressalta a importância de atentarmos para as muitas linguagens que podem compor o dia a dia das crianças, em diferentes momentos e espaços:

[...] como professoras devemos estar sempre atentas às informações, gestos, movimentos, ritmos e conceitos que chegam por diversos meios às crianças, desde as bem pequenas, e mesmo àqueles que oferecemos diariamente a elas dentro das Creches e NEls. Neste sentido, cabe considerarmos que os nossos corpos (de adultos) e das crianças devem ser "valorizados tendo como princípio o direito, a dignidade, a liberdade, o conhecimento, a sensibilidade e a vida em sua riqueza e totalidade" (LOPEZ, MENDES \& FARIA, 2006, p. I 2), assim temos que trabalhar intencionalmente em todos os tempos e espaços que compõem o cotidiano da educação infantil, as expressões, as características biológicas, físicas, psicológicas e culturais das crianças de forma indissociável (FLORIANÓPOLIS, NAP: Linguagens Corporais e Sonoras, 20|2, p.4).

Assim, quando propusemos acordar as crianças oferecendo-lhes música, como se fosse uma "serenata", em diferentes dias, estávamos abarcando o cotidiano da creche e a linguagem musical passou a integrar um momento da rotina do grupo. Essa vivência foi tão significativa para nós quanto para as crianças. O canto e a flauta, durante todo o estágio, se tornaram instrumentos fundamentais para a construção de uma relação afetiva com e entre as crianças, além de nos proporcionar a reflexão da importância desses momentos no cotidiano infantil. A serenata, não era só mais um elemento que trazíamos para o grupo, ela se tornou um elo entre nós e as crianças, como pudemos refletir em nosso registro:

Uma criança veio correndo me abraçar. Apertou-me tão forte como se estivesse agradecendo por tudo que aconteceu ali. E eu falei para ela: "você gostou?" E ela continuou abraçada. Penso que nesse momento tocamos seu coração de alguma forma. A música tem destas coisas! (Registro Andréa - 27 de maio de 2014). 
Imagens 12 e 13 - Estagiárias cantando e tocando para o momento de despertar
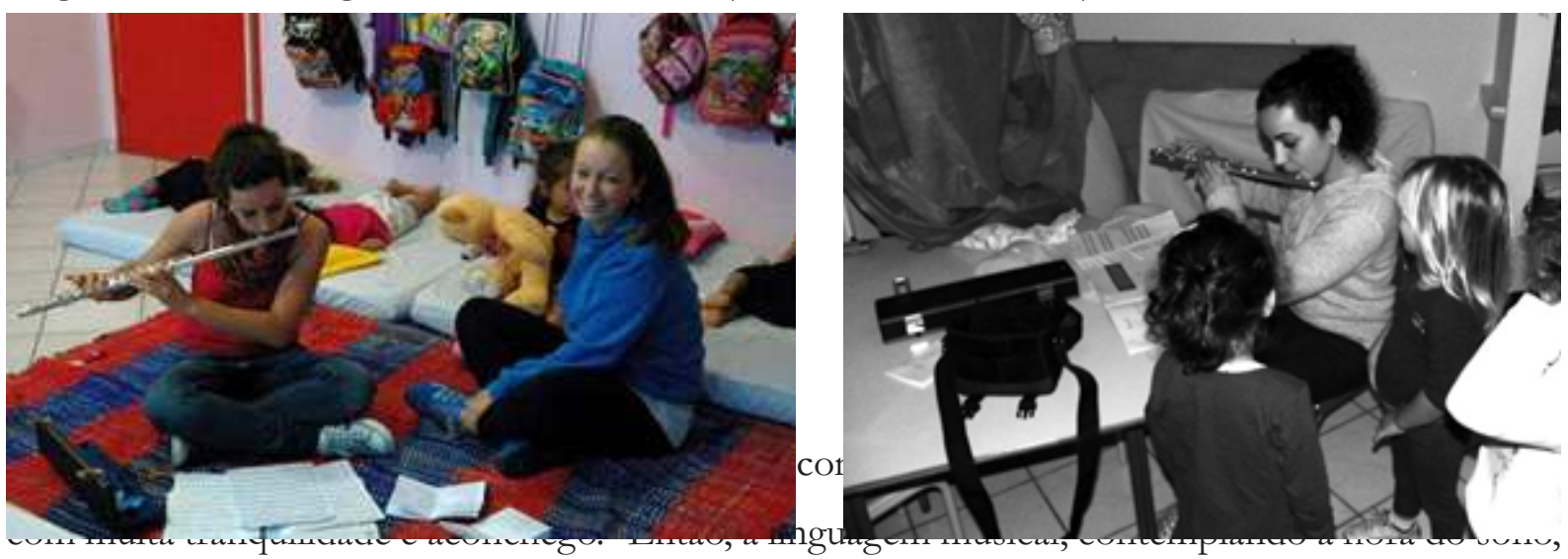

foi uma possibilidade clara de percebermos a não dissociabilidade do cuidar e educar na educação das crianças pequenas. O cuidado de si e do outro pulsava nessa vivência, e teoria e prática mais uma vez teceram uma linda conversa.

As linguagens orais e escritas também nos acompanharam durante este período de estágio. Em nosso percurso acadêmico, fomos nos constituindo apreciadoras da arte de contar e ler histórias e, também, contadoras de histórias, sendo assim, não poderíamos deixar de lado esse nosso desejo e gosto neste momento tão importante de nossas vidas. Então, organizamos espaços que proporcionassem a ampliação das possibilidades de comunicação e expressão das crianças, incluindo a apreciação de livros de literatura infantil e a narração oral de histórias. Segundo o NAP: Linguagens Oral e Escrita,

a perspectiva do trabalho pedagógico da linguagem oral e escrita no contexto da Educação Infantil deve contemplar sua função social, sua perspectiva da criação de sentidos, da expressão e comunicação, do seu caráter lúdico como aparece explicitamente em alguns poemas, travas-língua, cantigas e histórias de diferentes culturas. Ou seja, as práticas pedagógicas devem perspectivar o desenvolvimento e construção cada vez mais rica, significativa e complexa da gestualidade infantil, das suas narrativas, desenhos e palavras para que as crianças sejam contadoras-criadoras e leitoras de histórias sem fim! Que sejam capazes de (re)inventar o mundo dos sons, dos gestos e das palavras

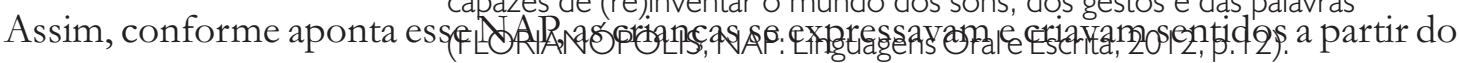
encontro com as narrativas e poemas já nas nossas primeiras semanas de observação. Mostravam-se contadoras e apreciadoras da arte de narrar histórias e a vontade de ouvir e contar histórias sempre partia delas: 
Antes mesmo de eu tirar da mochila os livros que havia pegado na biblioteca da creche, com a ideia de contar e dividir as histórias já que estava chovendo, um dos meninos veio com um livro que pertence ao grupo e pediu para eu contar! Quando eu mostrei os que eu havia trazido - grandes, coloridos, com formatos diferentes - ele ficou muito alegre e correu para o tapete. Depois que Déia e eu contamos e lemos muitas histórias, uma das meninas insistia que eu contasse novamente "O rei bigodeira e sua banheira". Disse que precisava fazer outras coisinhas, mas logo voltaria para contar. Foi um gesto proposital, pois ela demanda muita a nossa atenção e achei que seria bom para ela ficar um pouco sozinha com os livros. Quando me afastei percebemos que ela havia aberto o livro e estava contando sozinha. Folheava o livro e fazia os mesmos gestos que fiz para representar os personagens. É muito lindo ver como as crianças ressignificam o que trazemos a elas e "contam suas histórias" de uma forma tão individual e pura. É uma experiência fundamental poder ver na prática com as crianças o que tanto lemos nos livros e textos teóricos durante nossa formação(Registro Nina - 30 de abril).

Observar e participar dessa experiência nos fez refletir sobre como as crianças estão envoltas nesse mundo lúdico e maravilhoso. Para Eliane Debus (2006),

quem conta um conto aumenta um ponto, diz o ditado popular da tradição narrativa. Ao contar um conto, uma narrativa, um causo..., sem dúvida, aumenta-se um ponto. Um ponto na costura da sensibilidade, da emoção, do encantamento que existe na troca entre o ouvir e o narrar. Comunhão entre aquele que se aventura nas aventuras de contar e aquele que, encantado, aconchega a concha do ouvido mais perto para deliciar-se com a narrativa do outro que traz pela oralidade um mundo novo (p. 75).

Desta forma, foi possível "aumentar um ponto" e, ainda, contemplar na prática as indicações que nos traz o NAP: Linguagens Oral e Escrita (2012), o qual enfatiza a importância das crianças reinventarem seus mundos por meio das diversas linguagens.

\subsection{Organização dos Espaços e Materiais}

As diversas vivências que propusemos no decorrer do estágio também estavam relacionadas com a organização dos espaços e materiais. Nesse sentido, passamos a nos atentar para a importância desses espaços e dos materiais que o compõe em diferentes momentos da rotina. Organizamos espaços que possibilitassem as experiências e interações das crianças, estimulando-as a irem ao encontro dos novos elementos que trazíamos para sala. Para Horn (2004),

o olhar de um educador atento é sensível a todos os elementos que estão postos em uma sala de aula. $\bigcirc$ modo como organizamos materiais e móveis, e a forma como crianças e adultos ocupam esse espaço e como interagem com ele são reveladores de uma concepção pedagógica (p. 15$)$. 
Assim, nos distintos momentos e espaços em que organizamos os materiais para as crianças, procuramos desafiá-las a interagir com novas possibilidades. Como foi o caso do papel camurça preto, a curiosidade sobre aquela nova textura e cor provocava uma nova descoberta a elas. Deste modo, a intenção de disponibilizarmos a caixa com vários recipientes contendo lápis de cor e papéis diversificados para que as crianças pudessem desenhar, em diferentes momentos da rotina em que permanecíamos na sala, foi atingida sem didatizarmos ou condicionarmos aquela ação.

Imagem 14 - Desenho em papel camurça feito por uma das crianças do grupo

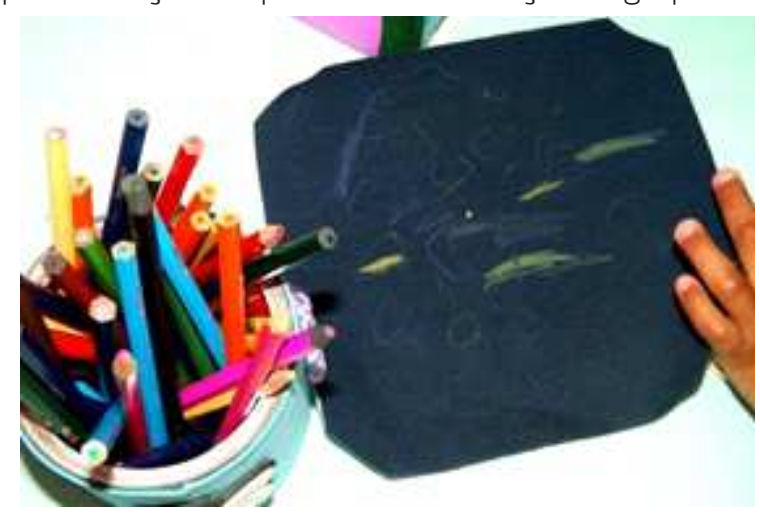

No período que antecedia a ida das crianças para casa era quando elas reinventavam as brincadeiras e os desenhos com mais amplitude, mas também era um momento que poucas ficavam na sala, pois as famílias vinham buscá-las. Talvez pelo fato de ficarem poucas crianças, elas interagiam mais intensamente conosco; com os espaços e com os diferentes materiais que disponibilizávamos. Era o momento em que a organização dos espaços e a disponibilidade dos materiais pulsavam com mais força, construindo um ambiente rico de trocas e aprendizagens. Nesse sentido, Horn (2004), a partir das contribuições de Zabalza e Forneiro (1998), expõe sobre a distinção entre espaços e ambiente, sem desconsiderar a ligação entre esses dois conceitos:

\footnotetext{
○ termo "espaços" se refere aos locais onde as atividades são realizadas, caracterizados por objetos, móveis, materiais didáticos, decoração. O termo "ambiente" diz respeito ao conjunto de espaços físicos e às relações que nele se estabelecem, as quais envolvem afeto e as relações interpessoais do processo, os adultos e as crianças; ou seja, em relação ao espaço temos as coisas postas em termos mais objetivos; em relação ao ambiente as mais subjetivas. Deste modo, não se considera apenas o meio físico ou material, mas também as interações resultantes dele (p.35).
}

Portanto, passamos a compreender que era a partir da organização dos espaços que o ambiente possibilitava relações afetivas, interpessoais e subjetivas. O registro a seguir expõe nitidamente essa relação: 
Sentei com algumas crianças na mesa para desenhar. Desenhei umas nuvens e uma menina que é uma criança que ainda tem um pouco de dificuldade na fala, falou para mim que ia desenhar uma nuvem. Desenhou e me mostrou, falei: você desenhou a boca; os olhos da nuvem? E ela disse: "não, é o vovô que mora lá, aí tem dias em que ele chora". Fiquei maravilhada com o desenho dela, pois representou muito bem um sentimento e com tanta sensibilidade que soube tocar meu coração (Registro Andréa - 20 de maio, de 2014).

O desenho dessa criança, e o que ela dizia sobre ele foi, mais um indicativo para pensarmos na importância da organização de espaços que propiciassem essas relações entre os objetos e sujeitos. A forma como procuramos organizar a sala visava à ação autônoma das crianças, mas pudemos perceber que essa organização também possibilitou a nossa autonomia e favoreceu nossa relação com as crianças. As caixas que preparamos, e deixamos ao alcance das crianças para que pudessem escolher os materiais e brinquedos, permitiram que nos entregássemos às relações com elas, que pudéssemos observar e participar das relações que estabeleciam com os materiais, entre si e conosco. Esses momentos planejados, na maioria das vezes para depois da janta até a hora de irmos embora, trouxeram a possibilidade de vivenciarmos plenamente a interlocução com as crianças, pois

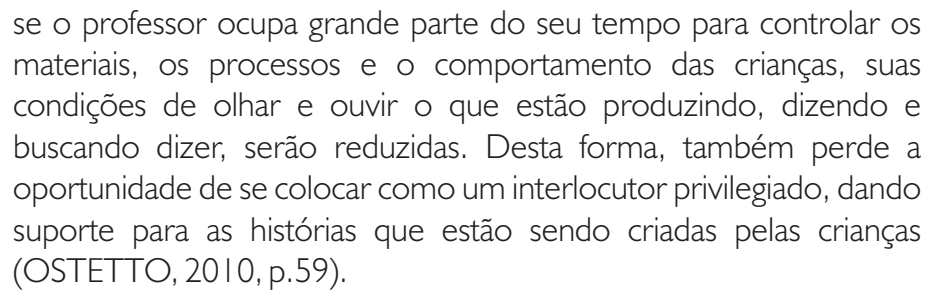

Em muitos momentos percebemos que era a partir da organização dos espaços e dos materiais disponibilizados que as crianças ampliavam as experiências vivenciadas: em uma bancada que organizávamos de diferentes formas, dependendo dos materiais de cada dia, as meninas imitavam a flauta e canto (serenata) e até o livro de literatura infantil se transformou num livro de partituras, imitando o livro que a estagiária Nina levara para os dias de serenata. A narrativa do Boi de Mamão, vivenciada anteriormente, também foi ressignificada pelas crianças e se transformou em enredo para o faz de conta: com a mesa de consultório médico montada, uma "paciente" era curada pelo "médico" que usava os brinquedos artesanais que havíamos feito para o grupo. 
Imagem 15 - Crianças tocando flauta com paus de chuva

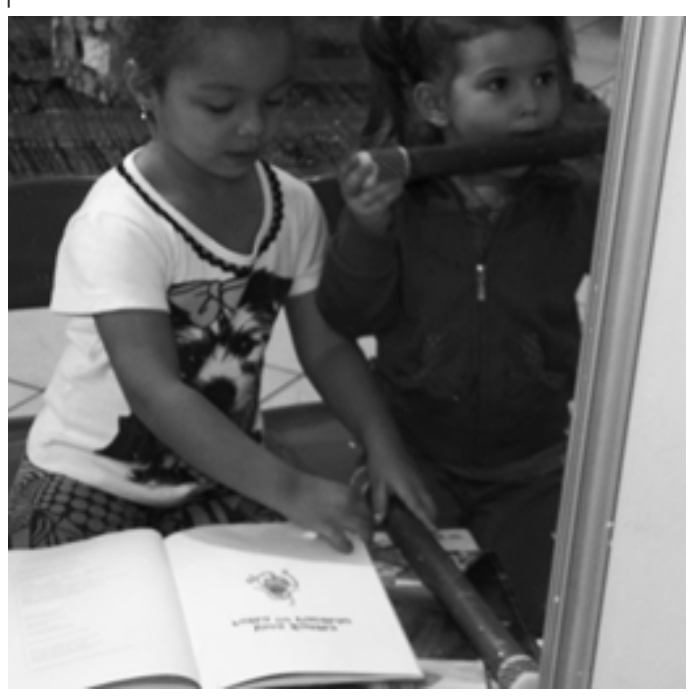

Imagem 16 - Crianças cuidando de uma menina"doente"

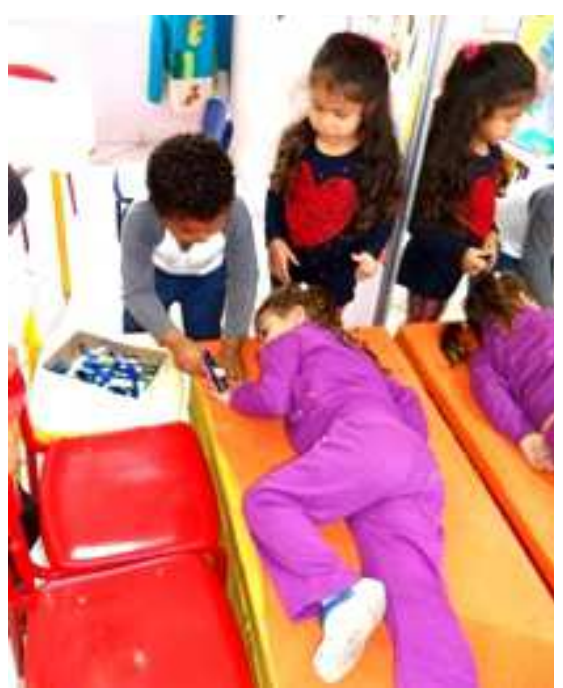

Assim, a cada dia que passava percebíamos a liberdade com que as crianças exploravam os espaços e materiais. Organizavam-se em pequenos grupos, ou até mesmo sozinhos, e significavam as brincadeiras na sala e nos momentos no parque. Para Guimarães (2006),

se considerarmos uma criança ativa, exploradora e criadora de sentidos, é preciso pensar um espaço e um educador que deem apoio aos seus movimentos, que incentivem sua autoria e autonomia, que contribuam para a diversificação de suas possibilidades. Compreender a educação como mobilizadora da capacidade da criança de produzir sentido sobre o mundo e não repetir padrões já existentes implica um desenho de espaço e um determinado papel de educador. Ou seja, é necessário levar em conta o diálogo com a expressividade das crianças, o incentivo às suas capacidades de criar cenas, narrativas (com vários suportes), invenção de situações, soluções inusitadas para as questões que emergem no coletivo, permitindo-lhes prosseguir, testar suas hipóteses, experimentar formas novas de relação, sustentar o que constroem. (p. 69)

A observação, o registro e a reflexão sobre as vivências que trouxemos neste tópico, evidenciaram que a organização dos espaços e a forma de disponibilizar materiais diversificados possibilitaram às crianças desenvolver e explorar suas potencialidades, autoria e autonomia. Dessa forma, tivemos mais dados para compreender a organização dos espaços e materiais como uma especificidade da docência na educação infantil.

\section{I.3 A partilha: relações entre adultos e crianças}

A experiência do estágio em Educação Infantil é um dos momentos mais ricos para a nossa formação. Aprendemos a partir das relações estabelecidas: com as crianças, professoras do grupo, 
funcionários da Instituição, professora orientadora, com o momento da troca de saberes entre as colegas da turma de estágio, com os estudos que tivemos que revisitar para planejar, para refletir, entre outras tantas coisas. Nesse sentido, a docência partilhada nos permitiu compreender que esses momentos de troca são fundamentais para pensarmos nas possibilidades de proposições de vivências e, também, para refletirmos sobre como as crianças pequenas interagem com as nossas práticas pedagógicas. Agora, rememorando a experiência da docência junto às crianças do G4B e nesse movimento de ir e vir, é impossível não falar do acolhimento e dos indicativos que as crianças nos davam. Desde o nosso primeiro encontro fomos surpreendidas por elas e por meio dessas atitudes a relação entre adultos e crianças se fortaleceu. Conforme apontam Gralik, Steinbach e BussSimão (2014), também a partir de uma experiência de docência,

\begin{abstract}
estar professora de educação infantil então é ser surpreendida constantemente pelas ações das crianças, é aprender a olhar e perceber a possibilidade de encantamento que reside nas coisas, aparentemente, mais simples: na água que escorre na torneira, no sol que brilha através da janela, no ruído da chuva, no punhado de terra, entre tantas coisas simples que fascinam. É, se posicionar em um lugar de aprendizado constante, pensando e repensando as práticas pedagógicas, refletindo sobre o que já se sabe e sobre aquilo que ainda se pode aprender acerca da infância (p. I28).
\end{abstract}

Esse "aprender a olhar" que as autoras se referem só foi possível porque lapidamos nosso olhar para ver. Estávamos confiantes que aprenderíamos a "ser/estar professoras" junto e com as crianças. Nesse sentido, as contribuições das crianças; as reflexões feitas junto às professoras do grupo e com nossa orientadora de estágio foram essenciais. Também concordamos com as autoras, quando consideram que,

[...] estar nessa profissão é aprender cotidianamente, é partilhar saberes, sentidos, significados, valores, experiências; tempos e espaços, com as crianças e com os outros profissionais que estão inseridos neste contexto, num processo de construção permanente (ibid., p. 128).

O processo de construção do trabalho pedagógico, planejamento, (re)planejamento e o não planejado (mudanças de rumos e frustrações), contribuíram para a nossa compreensão de que o trabalho docente jamais se dará por uma única via. O trabalho docente estará sempre entrelaçado entre as diversas vozes que o constitui.

\section{Considerações Finais}

Ao chegar ao fim da experiência aqui abordada, pudemos afirmar que "desfizemos" nossa bagagem durante o período que estivemos em contato com as crianças e profissionais da Creche 
Orlandina Cordeiro e também durante nossa imersão da escrita e reflexão do nosso memorial de estágio. Não só abrimos nosso baú - de estudos e experiências acumuladas durante a nossa vida e a nossa formação acadêmica vivenciada até aqui - para compartilhar saberes e sentimentos trazidos por nós, mas também deixamos que entrassem e se aconchegassem muitos outros saberes, conhecimentos, práticas, sentimentos que compartilhamos e partilhamos nessa nossa empreitada. Sem dúvida, foi uma experiência com amor, respeito e compreensão sobre a qual podemos dizer que recheou ainda mais nosso baú com cores lindas e fortes.

Foi uma trama complexa, como deve ser a prática docente. Foi um diálogo da prática com a teoria, como deve ser nossa formação inicial e a continuada, que se estende pelo resto de nossas vidas e em todos os âmbitos. Foi uma experiência para e com as crianças, a partir da qual pudemos perceber na prática a complexidade da docência e como suas especificidades são ricas e importantes para a compreendermos. A experiência do estágio também nos proporcionou conhecer e refletir sobre como são organizados os tempos e os espaços na instituição infantil e como as relações são constituídas neste espaço.

Ter a oportunidade de olhar, pensar e refletir criticamente sobre as nossas próprias ações, durante e após o vivido, possibilitou-nos crescimento pessoal e acadêmico, possibilitou-nos o entendimento sobre o lugar que estamos e onde queremos chegar. Nesse sentido, pensar sobre as especificidades da docência na Educação Infantil foi o que nos deu os caminhos para compreender a importância da nossa ação e relação com as crianças, do nosso modo de nos constituir professoras de crianças pequenas. 
Referências

BACHELARD, G. O ar e os sonhos: ensaios sobre a imaginação do movimento. São Paulo:

Martins Fontes, 1990. 275 p.

BACHELARD, G. A água e os sonhos: ensaios sobre a imaginação da matéria. São Paulo:

Martins Fontes, 1994. 202 p. [1989].

BORBA, Angela M. Quando as crianças brincam de ser adultos: vir-a-ser ou experiência da infância? In: LOPES, Jader Janer M. L.; MELLO, Marisol B. de. (Org.) O jeito de que nós crianças pensamos sobre certas coisas: dialogando com lógicas infantis. Rio de Janeiro: Rovelle, 2009, p. 97-117.

DEBUS, Eliane. Festaria de Brincança: a leitura literária na Educação Infantil. São Paulo: Paulus, 2006.

FLORIANÓPOLIS, PMF. SME. Orientações Curriculares para a Educação Infantil da Rede Municipal de Ensino de Florianópolis. Florianópolis: Prelo Gráfica e Editora Ltda., 2012. Disponível em:

$<$ http://www.pmf.sc.gov.br/entidades/educa/index.php?cms=legislacao ++ leis + e+ orientacoes\& menu=9>. Acesso em: 01 ago 2014

GIRARDELLO, Gilka. Imaginação: arte e ciência na infância. Pro-posições, Campinas, v.22, n.2, maio/ago, 2011. Disponível em:

$<$ http:/ / www.scielo.br/scielo.php?script=sci_arttext\&pid=S0103-

$73072011000200007 \& \operatorname{lng}=$ en\&nrm=iso $>$. Acesso em: 25 jul 2014

Uma clareira no bosque: contar histórias na escola. Campinas: Papirus, 2014.

GUIMARÃES, Daniela de Oliveira. Educação Infantil: Espaços e Experiências In: BRASIL Ministério da Educação e Cultura. Salto para o Futuro: O cotidiano na Educação Infantil. Brasília: MEC, 2006. Disponível em:

<http://www.tvbrasil.org.br/fotos/salto/series/175810Cotidiano.pdf>. Acesso em: 20 jun 2014

GRALIK, Carolina; STEINBACH, Flávia; BUSS-SIMÃO, Márcia. Prepara tudo que nós vamos brincar!:organizar espaços, possibilitar brincadeiras e experienciar a docência do estágio na educação infantil. Zero-a-seis. Florianópolis, v.1, n.29, 2014. Disponível em:

$<$ https://periodicos.ufsc.br/index.php/zeroseis/article/view/31976/26167>. Acesso em: 07 jul 2014

HORN, Maria da Graça Souza. Sabores, cores, sons, aromas: a organização dos espaços na educação infantil. Porto Alegre: Artmed, 2004

KRAMER, Sônia. A infância e sua singularidade. In: BEAUCHAMP, Jeanete; PAGEL, Sandra Denise; NASCIMENTO, Aricélia Ribeiro do (Orgs.). Ensino fundamental de nove anos: orientações para a inclusão da criança de seis anos de idade. Brasília: Ministério da Educação, Secretaria de Educação Básica, 2007. Disponível em:

$<$ http://portal.mec.gov.br/seb/arquivos/pdf/Ensfund/ensifund9anobasefinal.pdf $>$. Acesso em: 01 jun 2014

OSTETTO, Luciana Esmeralda. Planejamento na educação infantil: mais que a atividade, a criança em foco. In: OSTETTO, Luciana Esmeralda (Org.). Encontros e encantamentos na educação infantil: partilhando experiências de estágios. $7^{\mathrm{a}}$ ed. Campinas/ SP: Papirus, 2000. p. 175-200. 
OSTETTO, Luciana Esmeralda. Educação infantil, arte e criação: ensaios para transver o mundo. In: FLORIANÓPOLIS. Diretrizes educacionais pedagógicas para educação infantil. Prefeitura Municipal de Florianópolis. Secretaria Municipal de Educação. Florianópolis: Prelo Gráfica\& Editora Ltda, 2010. Disponível em:

<http://www.pmf.sc.gov.br/arquivos/arquivos/pdf/12_05_2010_15.24.41.03c7e67bbe979ef30c 2efe7d1db1468a.pdf>. Acesso em: 01 ago 2014

ROCHA, Eloísa Acires Candal; OSTETTO, Luciana Esmeralda. O estágio na formação universitária de professores de Educação Infantil. In: SEARA, Izabel Christine et al. (Orgs.). Práticas pedagógicas e estágios: diálogos com a cultura escolar. Florianópolis: Letras Contemporâneas, 2008, p. 103-116.

ROCHA, Eloisa Acires Candal. Diretrizes Educacionais Pedagógicas para Educação Infantil. In: FLORIANÓPOLIS. Orientações Curriculares para a educação infantil da rede municipal de Florianópolis. Prefeitura Municipal de Educação. Secretaria Municipal de Educação. Florianópolis: Prelo Gráfica\& Editora, 2010.

SCHMITT, Rosinete. Valdeci. O encontro com bebês e entre bebês: uma análise do entrelaçamento das relações. In: Rocha, Eloisa Acires Candal; Kramer, Sônia. (Org.). Educação Infantil: Enfoques em diálogos. Campinas: Papirus, 2011. 